\title{
ANALISIS KEBUTUHAN PELATIHAN STANDAR PENILAIAN BERBASIS DATA PEMETAAN MUTU PENDIDIKAN (PMP) PADA JENJANG SEKOLAH DASAR (SD) DI KOTA MAKASSAR
}

\author{
Nanang dan Rusman \\ Kementerian Pendidikan dan Kebudayaan dan Universitas Pendidikan Indonesia \\ e-mail: na2ng79@gmail.com
}

\begin{abstract}
Abstrak
Pemetaan mutu dilakukan untuk mengumpulkan, mengolah, menganalisis data dan informasi tentang capaian pemenuhan standar nasional pendidikan pada satuan pendidikan dari mulai tingkat satuan pendidikan, kabupaten/kota, provinsi, dan nasional. Tujuan penelitian ini adalah mendeskripsikan tentang analisis kebutuhan pelatihan tentang standar penilaian bagi guru sekolah dasar di Kota Makassar. Metode yang digunakan dalam penelitian ini adalah analisis deskriptif kuantitatif berdasarkan data rapot mutu tahun 2017. Hasil penelitian menunjukan dari 468 sekolah dasar di kota Makassar sebanyak 5 sekolah $(1,1 \%)$ masuk dalam kategori menuju SNP 2, 51 sekolah $(10,9 \%)$ masuk dalam kategori menuju SNP 3, 332 sekolah (70,9\%) masuk dalam kategori menuju SNP 4, 80 sekolah $(17,1 \%)$ masuk dalam kategori SNP dan tidak ada sekolah yang masuk dalam kategori menuju SNP 1. Simpulan dari penelitian ini adalah pemenuhan standar penilaian pendidikan bagi jenjang sekolah dasar di Kota Makassar masih berada pada kategori menuju SNP 4 sehingga masih memerlukan peningkatan capaian SPP dengan melalui pelatihan.
\end{abstract}

Kata Kunci: analisis kebutuhan, Standar Nasional Pendidikan (SNP), Standar Penilaian Pendidikan (SPP), pemetaan mutu pendidikan, rapor mutu

\section{ANALYSIS OF TRAINING NEEDS ASSESSMENT STANDARDS-BASED DATA MAPPING THE QUALITY OF EDUCATION AT THE PRIMARY LEVEL IN MAKASSAR}

\begin{abstract}
Quality mapping is done for collection, processing, analysis of data and information on the achievement of compliance with national standards of education in the educational unit of the start level of the educational unit until national levels. The purpose of this study was to describe the analysis of the training needs assessment standards for primary school teachers in Makassar. The method used in this research is quantitative descriptive analysis based on the data quality report in 2017. Research shows than 468 elementary schools in Makassar as many as 5 schools (1.1\%) belong to menuju SNP 2,51 schools (10.9\%) to SNP 3, 332 schools (70.9\%) to SNP 4, 80 schools (17.1\%) fall into SNP and no schools that fall within the heading to SNP 1. The conclusions of this study is the fulfillment of educational assessment standards for elementary school in Makassar is located in SNP 4 that still require standard performance improvement of education through training.
\end{abstract}

Keywords: needs analysis, the National Education Standards, Education Standards Assessment, mapping the quality of education, quality report card

\section{PENDAHULUAN}

Penilaian pembelajaran merupakan salah satu tugas guru yang terdapat dalam delapan Standar Nasional Pendidikan (SNP). Penilaian Pendidikan adalah krite- ria mengenai lingkup, tujuan, manfaat, prinsip, mekanisme, prosedur, dan instrumen penilaian hasil belajar peserta didik yang digunakan sebagai dasar dalam penilaian hasil belajar peserta didik pada 
pendidikan dasar dan pendidikan menengah. Penilaian Pendidikan termaktub dalam Peraturan Menteri Pendidikan dan Kebudayaan nomor 23 tahun 2016 mengatur tentang Standar Penilaian Pendidikan.

Permendikbud nomor 23 tahun 2016 pasal 4 dijelaskan tujuan penilaian sebagai berikut 1) Penilaian hasil belajar oleh pendidik bertujuan untuk memantau dan mengevaluasi proses, kemajuan belajar, dan perbaikan hasil belajar peserta didik secara berkesinambungan; 2) Penilaian hasil belajar oleh satuan pendidikan bertujuan untuk menilai pencapaian Standar Kompetensi Lulusan untuk semua mata pelajaran; dan 3) Penilaian hasil belajar oleh Pemerintah bertujuan untuk menilai pencapaian kompetensi lulusan secara nasional pada mata pelajaran tertentu.

Standar Penilaian Pendidikan disusun sebagai acuan penilaian bagi pendidik, satuan pendidikan dan pemerintah pada satuan pendidikan untuk jenjang pendidikan dasar dan menengah. Salah satu tugas guru dalam pembelajaran adalah melakukan penilaian pembelajaran sesuai dengan Standar Penilaian Pendidikan. Standar Nasional Pendidikan terdiri atas: 1) Standar Kompetensi Lulusan; 2) Standar Isi; 3) Standar Proses; 4) Standar Penilaian; 4) Standar Pendidik dan Tenaga Kependidikan; 5) Standar Pengelolaan; 6) Standar Sarana dan Prasarana; dan 7) Standar Pembiayaan.

Penjaminan mutu pendidikan mengacu pada standar sesuai peraturan yang berlaku. Acuan utamanya adalah Standar Nasional Pendidikan (SNP) yang telah ditetapkan sebagai kriteria minimal yang harus dipenuhi oleh satuan pendidikan dan penyelenggara pendidikan.

Pemetaan mutu adalah proses terkait kegiatan pengumpulan, pengolahan, analisis data dan informasi tentang capaian pemenuhan Standar Nasional Pendidikan dari mulai tingkat sekolah, kabupaten/ kota, provinsi hingga nasional. Pemetaan mutu memberikan gambaran kepada berbagai pemangku kepentingan tentang capaian pemenuhan Standar Nasional
Pendidikan. Pemetaan mutu dilakukan sebagai salah satu tahapan yang harus dilakukan dalam menjalankan penjaminan mutu pendidikan baik secara internal maupun eksternal. Pemetaan mutu ini menghasilkan peta mutu pendidikan yang dapat dimanfaatkan oleh sekolah, pemerintah daerah dan pemerintah sebagai acuan dalam perencanaan perbaikan dan peningkatan mutu pendidikan sesuai kewenangan masing masing.

Pemetaan mutu yang mengacu pada Standar Nasional Pendidikan menggunakan instrumen yang dikembangkan oleh Direktorat Jenderal Pendidikan Dasar dan Menengah. Standar Nasional Pendidikan dijabarkan dalam bentuk indikator mutu dan sub indikator mutu. Variabel pertanyaan dalam instrumen dibangun dari subindikator mutu dan diidentifikasi sumber data dan informasi yang mendu-kung. Instrumen pemetaan mutu berdasar-kan sumber data dan informasinya tersusun dalam dua jenis yaitu kuesioner pemetaan mutu dan formulir data pokok pendidikan. Data dan informasi untuk formulir data pokok pendidikan diambil dari rekam data sekolah yang ada pada Pusat data dan Statistik Pendidikan dan Kebudayaan. Data dan informasi untuk kuesioner pemetaan mutu dihimpun kembali ke sekolah. Sekolah melakukan kegiatan pemetaan mutu melalui Evaluasi Diri Sekolah (EDS) dan menyampaikan hasil evaluasi diri tersebut dalam bentuk data dan informasi sesuai dengan instrumen pemetaan mutu yang dikembangkan oleh Direktorat Jenderal Pendidikan Dasar dan Menengah dengan ketentuan yang ada. Data dan informasi tersebut dikirimkan ke system informasi mutu pendidikan untuk diolah menjadi peta mutu yang memuat capaian pemenuhan terhadap standar nasional pendidikan untuk disampaikan kepada sekolah, pemerintah daerah dan pemerintah pusat. Peta mutu dianalisa lebih lanjut sehingga dapat digunakan sebagai acuan perencanaan pendidikan oleh sekolah, pemerintah daerah dan pusat sebagai upaya pemenuhan mutu pendidi- 
kan berjalan sinergis karena berasal dari sumber data dan informasi yang sama.

Penelitian ini mengkaji mengenai apakah Standar Penilaian yang ada di sekolah dasar di Kota Makassar sudah memenuhi Standar Nasional Pendidikan atau masih ada kesenjangan dengan Standar Nasional Pendidikan. Penelitian ini fokus mengkaji sejauh mana pencapaian standar penilaian pendidikan pada jenjang sekolah dasar di kota Makassar sesuai dengan standar penilaian pendidikan dalam Peraturan Menteri Pendidikan dan Kebudayaan Republik Indonesia Nomor 23 Tahun 2016 Tentang Standar Penilaian Pendidikan.

Kemampuan guru dalam melakukan penilaian dalam pembelajaran sangat diperlukan. Kurikulum 2013 mengisyaratkan ada tiga ranah yang harus dinilai oleh guru pada peserta didiknya, yaitu pengetahuan, sikap, dan keterampilan. Untuk menilai ketiga ranah tersebut, kurikulum 2013 merekomendasikan lima karakteristik penilaian, yaitu: belajar tuntas, autentik, berkesinambungan, berdasarkan acuan kriteria, menggunakan teknik penilaian yang bervariasi. Implementasi Kurikulum 2013, untuk semua tingkat satuan pendidikan berimplikasi pada proses penilaian pencapaian kompetensi peserta didik. Penilaian pencapaian kompetensi oleh pendidik dilakukan untuk memantau proses, kemajuan, perkembangan pencapaian kompetensi peserta didik sesuai dengan potensi yang dimiliki dan kemampuan yang diharapkan secara berkesinambungan. Penilaian juga dapat memberikan umpan balik kepada pendidik agar dapat menyempurnakan perencanaan dan proses pembelajaran (Peraturan Menteri Pendidikan dan Kebudayaan No. 66 Tahun 2013 tentang Standar Penilaian Pendidikan) kemampuan guru dalam melakukan penilaian pembelajaran melekat pada kompetensi pedagogik, profesional, sosial, dan kepribadian guru. Mengingat betapa pentingnya standar penilaian pendidikan, dan diperlukannya kemampuan guru dalam melakukan penilaian, maka penelitian untuk memperoleh gambaran analisis kebutuhan pelatihan standar penilaian pada jenjang sekolah dasar di kota Makassar.

\section{METODE}

Metode yang digunakan dalam penelitian adalah survei tipe crosssectional, karena penyebaran instrumen untuk di sekolah dilaksanakan dalam satu waktu pengambilan data (Creswell, 2014; Ali, 2014). Pengumpulan data dengan instrumen berupa angket dilakukan selama Juni sampai September 2017 sesuai jadwal pengumpulan data pemetaan mutu Direktorat Jenderal Pendidikan Dasar dan Menengah yang dilakukan petugas pemetaan mutu di bawah koordinasi Lembaga Penjaminan Mutu Pendidikan (LPMP) Sulawesi Selatan. Responden dalam penelitian ini berasal dari 468 sekolah yang terdiri atas kepala sekolah, pengawas pembina, guru, dan komite sekolah. Sebaran responden terlihat pada tabel 1 .

Tabel 1. Sebaran Responden Per Sekolah

\begin{tabular}{clc}
\hline No & \multicolumn{1}{c}{$\begin{array}{c}\text { Guru Tingkat } \\
\text { Sekolah }\end{array}$} & Jumlah \\
\hline 1 & Kepala Sekolah & 1 orang \\
2 & Pengawas Pembina & 1 orang \\
3 & Guru & $8-10$ orang \\
4 & Komite Sekolah & 3 orang \\
\hline
\end{tabular}

Penetapan sampel penelitian dilakukan dengan menggunakan teknik penyampelan seadanya (Sudjana, 2013). Jumlah responden dari 468 sekolah diasumsikan mewakili populasi guru di sekolah. Semua guru di sekolah dianggap memiliki kriteria sama, peneliti hanya menunggu berapa pun jumlah angket yang kembali dalam jangka waktu yang telah ditentukan, instrumen tersebut diinput melalui aplikasi PMP kemudian diolah dan dianalisis dalam aplikasi PMP kemudian disajikan dalam Rapor Mutu. Indikator yang ditanyakan dalam angket meliputi: 1) Aspek penilaian sesuai ranah kompetensi, 2) Teknik penilaian objektif dan akuntabel, 3) Penilaian pendidikan ditindaklanjuti, 4) Instrumen penilaian menyesuaikan aspek, 5) penilaian dilakukan mengikuti prosedur. 
Data angket kemudian diolah dan disajikan dalam bentuk persentase dan grafik. Selanjutnya data dianalisis secara deskriptif, yaitu dengan mendeskripsikan hasil yang diperoleh kemudian memaknainya (Creswell, 2014).

\section{HASIL DAN PEMBAHASAN Hasil}

Dari isian angket 468 sekolah responden, diperoleh hasil penelitian tentang pemenuhan Standar Penilaian Pendidikan jenjang sekolah dasar adalah sebagai berikut:

\section{Aspek Penilaian Sesuai Ranah Kompetensi}

Untuk indikator aspek penilaian sesuai ranah kompetesi yang terdiri dari dua sub indikator yaitu pertama, mencakup ranah sikap, pengetahuan dan keterampilan. Kedua, memiliki bentuk pelaporan sesuai dengan ranah. Pemenuhan standar pendidikan pada indikator aspek penilaian sesuai ranah kompetesi ditunjukan pada tabel 2.

Tabel 2. Aspek Penilaian Sesuai Ranah Kompetensi

\begin{tabular}{clc}
\hline No & $\begin{array}{c}\text { Kategori } \\
\text { Capaian }\end{array}$ & Jumlah Sekolah \\
\hline 1 & Menuju SNP 1 & 0 \\
2 & Menuju SNP 2 & 2 \\
3 & Menuju SNP 3 & 20 \\
4 & Menuju SNP 4 & 135 \\
5 & SNP & 311 \\
\hline
\end{tabular}

Sebanyak 311 sekolah (66.5\%) sudah mencapai kategori SNP, 135 sekolah (28.8\%) masuk kategori menuju SNP 4, 20 sekolah $(4.3 \%)$ masuk kategori menuju SNP 3, 2 sekolah (0.4\%) masuk kategori menuju SNP 2 dan tidak ada sekolah yang masuk kategori menuju SNP 1.

\section{Mencakup Ranah Sikap, Pengetahuan dan Keterampilan}

Pemenuhan standar penilaian pada sub indikator mencakup ranah sikap, pengetahuan dan keterampilan diperlihatkan dalam gambar berikut ini:

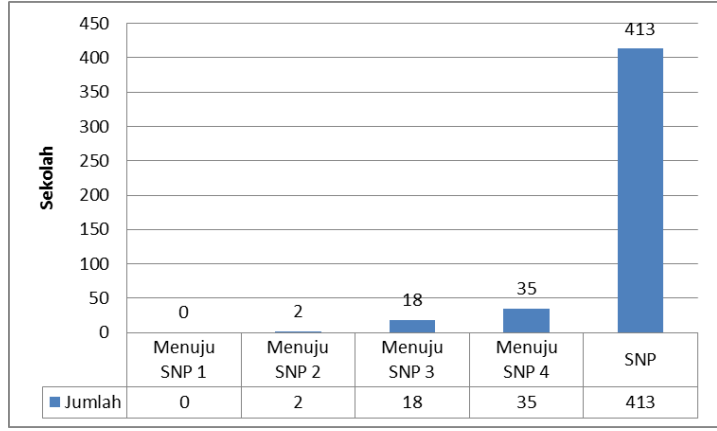

Gambar 1. Mencakup Ranah Sikap, Pengetahuan dan Keterampilan

Sebanyak 413 sekolah (88.2\%) sudah mencapai kategori SNP, 35 sekolah (7.5\%) masuk kategori menuju SNP 4, 18 sekolah (3.8\%) masuk kategori menuju SNP 3, 2 sekolah $(0.4 \%)$ masuk kategori menuju SNP 2 dan tidak ada sekolah yang masuk kategori menuju SNP 1.

\section{Memiliki Bentuk Pelaporan Sesuai dengan Ranah}

Pemenuhan standar penilaian pada sub indikator memiliki bentuk pelaporan sesuai dengan ranah diperlihatkan dalam gambar berikut ini:

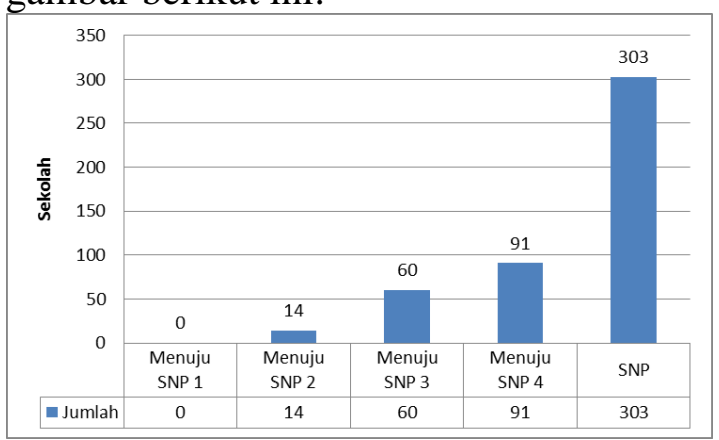

Gambar 2. Memiliki Bentuk Pelaporan Sesuai dengan Ranah

Sebanyak 303 sekolah (64.7\%) sudah mencapai kategori SNP, 91 sekolah (19.4\%) masuk kategori menuju SNP 4, 60 sekolah (12.8\%) masuk kategori menuju SNP 3, 14 sekolah (3.0\%) masuk kategori menuju SNP 2 dan tidak ada sekolah yang masuk kategori menuju SNP 1.

\section{Teknik Penilaian Obyektif dan Akuntabel}

Untuk indikator teknik penilaian obyektif dan akuntabel terdiri dari dua sub indikator yaitu pertama, menggunakan jenis 
teknik penilaian yang obyektif dan akuntabel. Kedua, memiliki perangkat teknik penilaian lengkap. Pemenuhan standar pendidikan pada indikator teknik penilaian obyektif dan akuntabel ditunjukan pada tabel 3 .

Tabel 3. Teknik Penilaian Obyektif dan Akuntabel

\begin{tabular}{clc}
\hline No & $\begin{array}{c}\text { Kategori } \\
\text { Capaian }\end{array}$ & $\begin{array}{c}\text { Jumlah } \\
\text { Sekolah }\end{array}$ \\
\hline 1 & Menuju SNP 1 & 0 \\
2 & Menuju SNP 2 & 25 \\
3 & Menuju SNP 3 & 81 \\
4 & Menuju SNP 4 & 251 \\
5 & SNP & 111 \\
\hline
\end{tabular}

Sebanyak 111 sekolah (23.7\%) sudah mencapai kategori SNP, 251 sekolah (53.6\%) masuk kategori menuju SNP 4, 81 sekolah $(17.3 \%)$ masuk kategori menuju SNP, 3,25 sekolah (5.3\%) masuk kategori menuju SNP 2 dan tidak ada sekolah yang masuk kategori menuju SNP 1.

\section{Menggunakan Jenis Teknik Penilaian yang Obyektif dan Akuntabel}

Pemenuhan standar penilaian pada sub indikator menggunakan jenis teknik penilaian yang obyektif dan akuntabel diperlihatkan dalam gambar berikut ini:

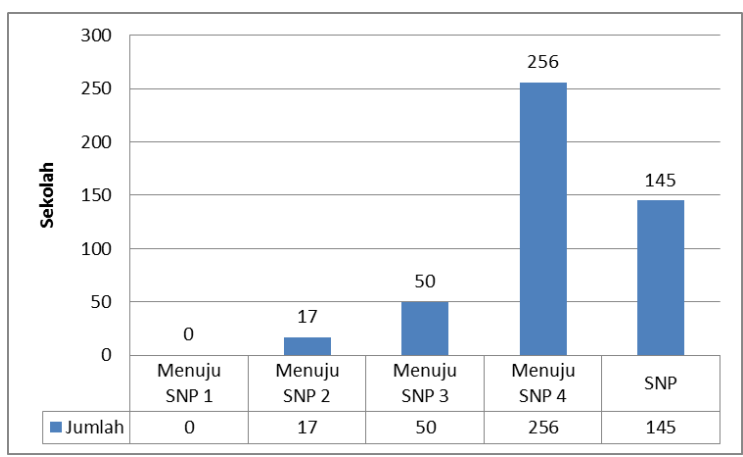

Gambar 3. Menggunakan Jenis Teknik Penilaian yang Obyektif dan Akuntabel

Sebanyak 145 sekolah (31\%) sudah mencapai kategori SNP, 256 sekolah $(54.7 \%)$ masuk kategori menuju SNP 4, 50 sekolah $(10.7 \%)$ masuk kategori menuju SNP 3, 17 sekolah (3.6\%) masuk kategori menuju SNP 2 dan tidak ada sekolah yang masuk kategori menuju SNP 1.

\section{Memiliki Perangkat Teknik Penilaian Lengkap}

Pemenuhan standar penilaian pada sub indikator memiliki perangkat teknik penilaian lengkap diperlihatkan dalam gambar berikut ini:

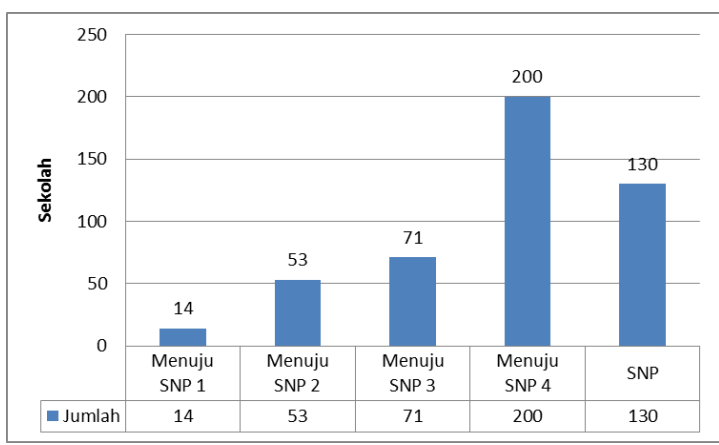

Gambar 4. Memiliki Perangkat Teknik Penilaian Lengkap

Sebanyak 130 sekolah (27.8\%) sudah mencapai kategori SNP, 200 sekolah (42.7\%) masuk kategori menuju SNP 4, 71 sekolah $(15.2 \%)$ masuk kategori menuju SNP 3, 53 sekolah (11.3\%) masuk kategori menuju SNP 2 dan 14 sekolah (3\%) yang masuk kategori menuju SNP 1.

\section{Penilaian \\ Ditindaklanjuti}

Pendidikan

Untuk indikator penilaian pendidikan ditindaklanjuti yang terdiri dari dua sub indikator yaitu pertama, menindaklanjuti hasil pelaporan penilaian. Kedua, melakukan pelaporan penilaian secara periodik. Pemenuhan standar pendidikan pada indikator penilaian pendidikan ditindaklanjuti ditunjukan pada tabel 4 .

Tabel 4. Penilaian Pendidikan Ditindaklanjuti

\begin{tabular}{clc}
\hline No & Kategori Capaian & $\begin{array}{c}\text { Jumlah } \\
\text { Sekolah }\end{array}$ \\
\hline 1 & Menuju SNP 1 & 0 \\
2 & Menuju SNP 2 & 4 \\
3 & Menuju SNP 3 & 38 \\
4 & Menuju SNP 4 & 278 \\
5 & SNP & 148 \\
\hline
\end{tabular}


Sebanyak 148 sekolah (31.6\%) sudah mencapai kategori SNP, 278 sekolah (59.4\%) masuk kategori menuju SNP 4, 38 sekolah $(8.1 \%)$ masuk kategori menuju SNP 3, 4 sekolah (0.9\%) masuk kategori menuju SNP 2 dan tidak ada sekolah yang masuk kategori menuju SNP 1.

\section{Menindaklanjuti Hasil Pelaporan Penilaian}

Pemenuhan standar penilaian pada sub indikator Menindaklanjuti hasil pelaporan penilaian diperlihatkan dalam gambar berikut ini:

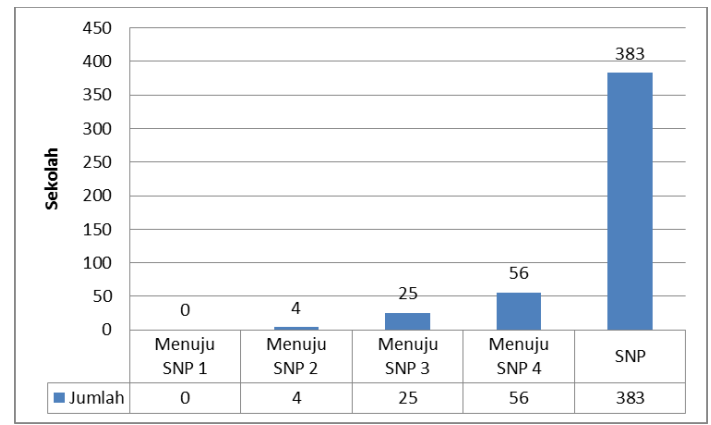

Gambar 5. Menindaklanjuti Hasil Pelaporan Penilaian

Sebanyak 383 sekolah (81.8\%) sudah mencapai kategori SNP, 56 sekolah (12.0\%) masuk kategori menuju SNP 4, 25 sekolah (5.3\%) masuk kategori menuju SNP 3, 4 sekolah (0.9\%) masuk kategori menuju SNP 2 dan tidak ada sekolah yang masuk kategori menuju SNP 1.

\section{Melakukan Pelaporan Penilaian Secara Periodik}

Pemenuhan standar penilaian pada sub indikator Melakukan pelaporan penilaian secara periodik diperlihatkan dalam gambar berikut ini:

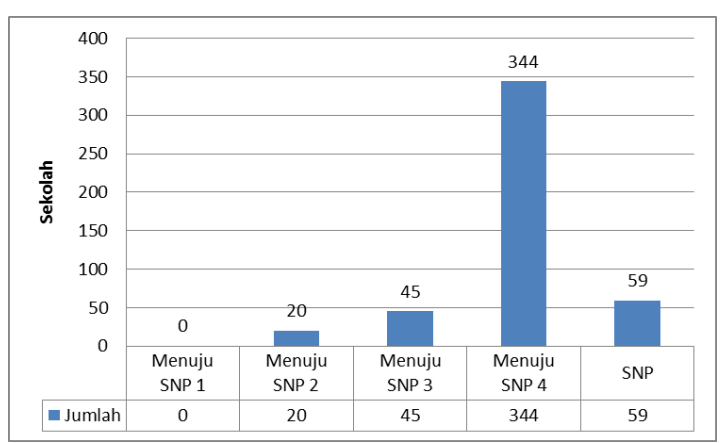

Gambar 6. Melakukan Pelaporan Penilaian secara Periodik
Sebanyak 59 sekolah (12.6\%) sudah mencapai kategori SNP, 344 sekolah (73.5\%) masuk kategori menuju SNP 4, 45 sekolah $(9.6 \%)$ masuk kategori menuju SNP 3, 20 sekolah (4.3\%) masuk kategori menuju SNP 2 dan tidak ada sekolah yang masuk kategori menuju SNP 1.

\section{Instrumen Penilaian Menyesuaikan Aspek}

Indikator instrumen penilaian menyesuaikan aspek yang terdiri dari tiga sub indikator yaitu pertama, menggunakan instrumen penilaian aspek sikap. Kedua, menggunakan instrumen penilaian aspek pengetahuan. Ketiga, menggunakan instrumen penilaian aspek keterampilan. Pemenuhan standar pendidikan pada indikator instrumen penilaian menyesuaikan aspek ditunjukan pada tabel 5.

Tabel 5. Instrumen Penilaian Menyesuaikan Aspek

\begin{tabular}{clc}
\hline No & $\begin{array}{c}\text { Kategori } \\
\text { Capaian }\end{array}$ & Jumlah Sekolah \\
\hline 1 & Menuju SNP 1 & 3 \\
2 & Menuju SNP 2 & 43 \\
3 & Menuju SNP 3 & 77 \\
4 & Menuju SNP 4 & 221 \\
5 & SNP & 124 \\
\hline
\end{tabular}

Sebanyak 124 sekolah (26.5\%) sudah mencapai kategori SNP, 221 sekolah (47.2\%) masuk kategori menuju SNP 4, 77 sekolah (16.5\%) masuk kategori menuju SNP 3, 43 sekolah (9.2\%) masuk kategori menuju SNP 2 dan 3 sekolah $(0,6 \%)$ yang masuk kategori menuju SNP 1.

\section{Menggunakan Instrumen Penilaian Aspek Sikap}

Pemenuhan standar penilaian pada sub indikator menggunakan instrumen penilaian aspek sikap diperlihatkan dalam gambar berikut ini: 


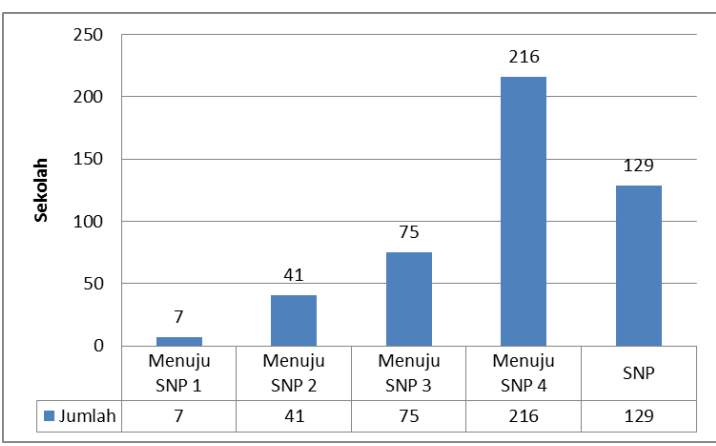

Gambar 7. Menggunakan Instrumen Penilaian Aspek Sikap

Sebanyak 129 sekolah (27.6\%) sudah mencapai kategori SNP, 216 sekolah (46.2\%) masuk kategori menuju SNP 4, 75 sekolah (16.0\%) masuk kategori menuju SNP 3, 41 sekolah (8.8\%) masuk kategori menuju SNP 2 dan 7 sekolah (1,5\%) yang masuk kategori menuju SNP 1.

\section{Menggunakan Instrumen Penilaian Aspek Pengetahuan}

Pemenuhan standar penilaian pada sub indikator menggunakan instrumen penilaian aspek pengetahuan diperlihatkan dalam gambar berikut ini:

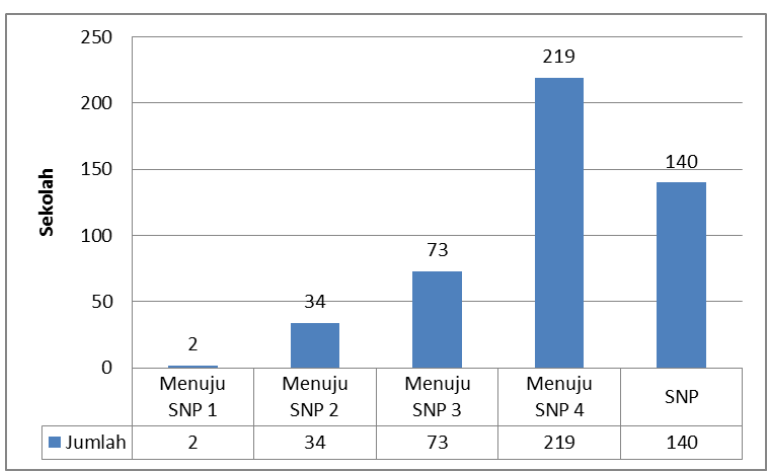

Gambar 8. Menggunakan Instrumen

Penilaian Aspek Pengetahuan

Sebanyak 140 sekolah (29.9\%) sudah mencapai kategori SNP, 219 sekolah (46.8\%) masuk kategori menuju SNP 4, 73 sekolah (15.6\%) masuk kategori menuju SNP 3, 34 sekolah (7.3\%) masuk kategori menuju SNP 2 dan 2 sekolah $(0,4 \%)$ yang masuk kategori menuju SNP 1.

\section{Menggunakan Instrumen Penilaian Aspek Keterampilan}

Pemenuhan standar penilaian pada sub indikator menggunakan instrumen penilaian aspek keterampilan diperlihatkan dalam gambar berikut ini:

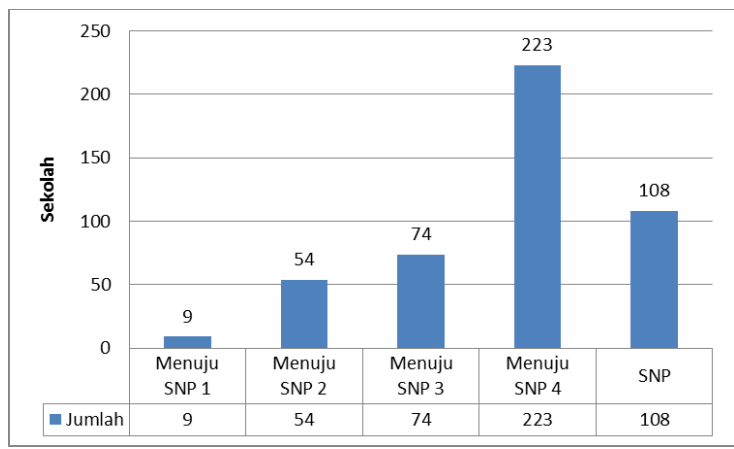

Gambar 9. Menggunakan Instrumen Penilaian Aspek Keterampilan

Sebanyak 108 sekolah (23.1\%) sudah mencapai kategori SNP, 223 sekolah (27.6\%) masuk kategori menuju SNP 4, 74 sekolah $(15.8 \%)$ masuk kategori menuju SNP 3, 54 sekolah (11.5\%) masuk kategori menuju SNP 2 dan 9 sekolah (1,9\%) yang masuk kategori menuju SNP 1.

\section{Penilaian Dilakukan Mengikuti Prosedur \\ Indikator penilaian dilakukan mengi-} kuti prosedur yang terdiri dari tiga sub indikator yaitu pertama, melakukan penilaian berdasarkan penyelenggara sesuai prosedur. Kedua, melakukan penilaian berdasarkan ranah sesuai prosedur. Ketiga, menentukan kelulusan siswa berdasarkan pertimbangan yang sesuai. Pemenuhan standar pendidikan pada indikator penilaian dilakukan mengikuti prosedur ditunjukan pada tabel 6.

Tabel 6. Penilaian Dilakukan Mengikuti Prosedur

\begin{tabular}{clc}
\hline No & $\begin{array}{c}\text { Kategori } \\
\text { Capaian }\end{array}$ & Jumlah Sekolah \\
\hline 1 & Menuju SNP 1 & 0 \\
2 & Menuju SNP 2 & 7 \\
3 & Menuju SNP 3 & 51 \\
4 & Menuju SNP 4 & 410 \\
5 & SNP & 0 \\
\hline
\end{tabular}

Tidak ada sekolah mencapai kategori SNP, 410 sekolah (87.6\%) masuk kategori menuju SNP 4, 51 sekolah (10.9\%) masuk kategori menuju SNP3, 7 sekolah (1.5\%) 
masuk kategori menuju SNP 2 dan tidak ada sekolah yang masuk kategori menuju SNP 1.

\section{Melakukan Penilaian Berdasarkan Penyelenggara Sesuai Prosedur}

Pemenuhan standar penilaian pada sub indikator melakukan penilaian berdasarkan penyelenggara sesuai prosedur diperlihatkan dalam gambar berikut ini:

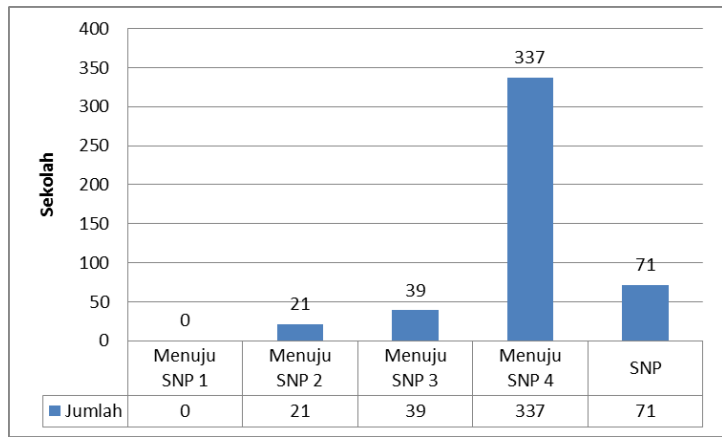

Gambar 10. Melakukan Penilaian

Berdasarkan Penyelenggara Sesuai Prosedur

Sebanyak 71 sekolah (15.2\%) sudah mencapai kategori SNP, 337 sekolah (72.0\%) masuk kategori menuju SNP 4, 39sekolah $(8.3 \%)$ masuk kategori menuju SNP 3, 21 sekolah (4.5\%) masuk kategori menuju SNP 2 dan tidak ada sekolah yang masuk kategori menuju SNP 1.

\section{Melakukan Penilaian Berdasarkan Ranah Sesuai Prosedur}

Pemenuhan standar penilaian pada sub indikator melakukan penilaian berdasarkan ranah sesuai prosedur diperlihatkan dalam gambar berikut ini:

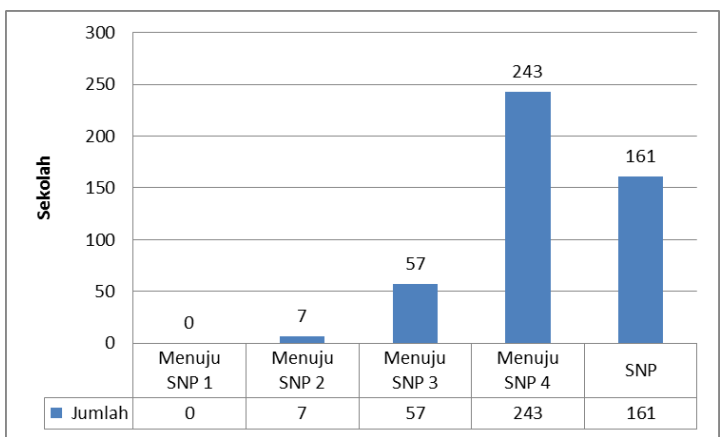

Gambar11. Penilaian Berdasarkan Ranah Sesuai Prosedur
Sebanyak 161 sekolah (34.4\%) sudah mencapai kategori SNP, 243 sekolah (51.9\%) masuk kategori menuju SNP 4, 57 sekolah (12.2\%) masuk kategori menuju SNP 3, 7 sekolah (1.5\%) masuk kategori menuju SNP 2 dan tidak ada sekolah yang masuk kategori menuju SNP 1.

\section{Menentukan Kelulusan Siswa Berdasarkan Pertimbangan yang Sesuai}

Pemenuhan standar penilaian pada sub indikator menentukan kelulusan siswa berdasarkan pertimbangan yang sesuai diperlihatkan dalam gambar berikut ini:

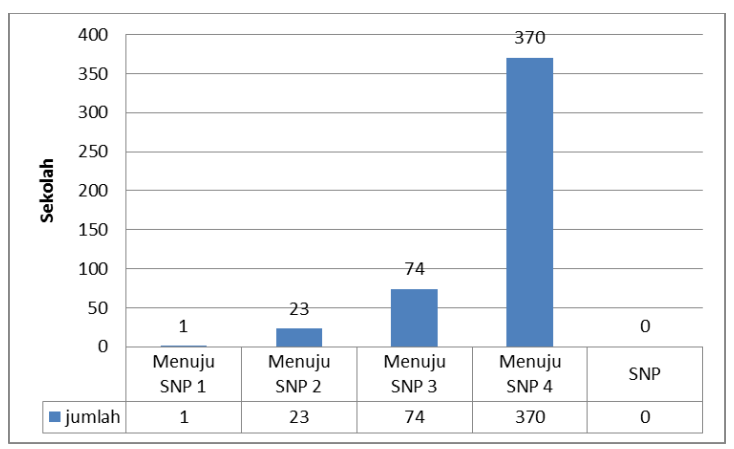

Gambar 12. Menentukan Kelulusan Siswa

Berdasarkan Pertimbangan yang Sesuai

Tidak ada sekolah yang mencapai kategori SNP, 370 sekolah (79.1\%) masuk kategori menuju SNP 4, 74 sekolah (15.8\%) masuk kategori menuju SNP 3, 23 sekolah (4.9\%) masuk kategori menuju SNP 2 dan 1 sekolah $(0.2 \%)$ yang masuk kategori menuju SNP 1.

\section{PEMBAHASAN}

Program pengumpulan data Pemetaan Mutu Pendidikan melalui aplikasi PMP sudah berlangsung dari tahun 2016. Undang-undang Nomor 20 Tahun 2003 tentang Sistem Pendidikan Nasional menyatakan bahwa Sistem Pendidikan Nasional adalah keseluruhan komponen pendidikan yang saling terkait secara terpadu untuk mencapai tujuan pendidikan nasional. Pendidikan nasional bertujuan mengembangkan kemampuan dan membentuk watak serta peradaban bangsa yang bermartabat dalam rangka mencerdaskan kehidupan bangsa, bertujuan untuk berkembangnya potensi peserta didik agar menjadi 
manusia yang beriman dan bertakwa kepada Tuhan Yang Maha Esa, berakhlak mulia, sehat, berilmu, cakap, kreatif, mandiri, dan menjadi warga negara yang demokratis serta bertanggung jawab. Peraturan Pemerintah Republik Indonesia Nomor 19 tahun 2005 tentang Standar Nasional Pendidikan mengamanatkan bahwa setiap Satuan Pendidikan pada jalur formal dan nonformal wajib melakukan penjaminan mutu pendidikan. Penjaminan mutu pendidikan bertujuan untuk memenuhi atau melampaui Standar Nasional Pendidikan. Sebagaimana diatur dalam Peraturan Pemerintah Nomor 32 Tahun 2013 dan Peraturan Pemerintah Nomor 13 Tahun 2015, Lembaga Penjaminan Mutu Pendidikan yang selanjutnya disebut LPMP sebagai unit pelaksana teknis Kementerian yang berkedudukan di provinsi bertugas untuk membantu Pemerintah Daerah dalam bentuk supervisi, bimbingan, arahan, saran, dan bantuan teknis kepada satuan pendidikan dasar dan menengah serta Pendidikan Nonformal, dalam berbagai upaya penjaminan mutu satuan pendidikan untuk mencapai Standar Nasional Pendidikan.

Penjaminan mutu pendidikan ini merupakan tanggung jawab dari setiap komponen di satuan pendidikan. Sesuai peraturan perundangan yang berlaku setiap satuan pendidikan wajib melakukan penjaminan mutu sesuai kewenangannya. Peningkatan mutu di satuan pendidikan tidak dapat berjalan dengan baik tanpa adanya budaya mutu pada seluruh komponen sekolah. Untuk peningkatan mutu sekolah secara utuh dibutuhkan pendekatan khusus agar seluruh komponen sekolah bersama-sama memiliki budaya mutu. Untuk itu dibutuhkan program Implementasi Penjaminan Mutu Pendidikan di seluruh sekolah di Indonesia dengan pendekatan pelibatan seluruh komponen sekolah (whole school approach).

Sebagai langkah awal rangkaian kegiatan penjaminan mutu yang dilaksanakan oleh satuan pendidikan, setiap satuan pendidikan harus mampu melakukan pemetaan mutu pendidikan. Pemetaan ini diperlukan agar setiap satuan pendidikan dapat mengidentifikasi kekuatan dan kelemahan masing-masing berkaitan dengan pencapaian Standar Nasional Pendidikan. Data untuk pemetaan mutu pendidikan diambil dari aplikasi Dapodik dan pengumpulan data PMP. Dapodik memuat data pencapaian indikator SNP pada Standar PTK, Sarana Prasarana, dan Pembiayaan. Sedangkan aplikasi PMP memuat indikator SNP untuk 5 standar lainnya yaitu Standar Kompetensi Lulusan, Standar Isi, Standar Proses, Standar Penilaian, dan Standar Pengelolaan. Kedua aplikasi ini diisi oleh setiap satuan pendidikan dengan sejumlah responden yang telah ditentukan, kemudian disinkronisasi/dikirimkan ke server pusat pendataan untuk diolah dan dipetakan. Hasil pemetaan ini selanjutnya dijadikan acuan dalam rangka penyusunan rencana pemenuhan 8 Standar Nasional Pendidikan sebagai acuan mutu pendidikan, informasi atas keterlaksanaan dan ketercapaian 8 SNP.

Untuk meneliti analisis kebutuhan pelatihan standar penilaian, peneliti memfokuskan pada jenjang Sekolah Dasar di Kota Makassar. Standar Penilaian Pendidikan yang dijadikan acuan adalah Standar Penilaian Pendidikan dalam Peraturan Menteri Pendidikan dan kebudayaan Nomor 23 tahun 2016. Sehingga kajian Analisis kebutuhan pelatihan pun ditinjau dari standar penilaian pendidikan. Standar Penilaian Pendidikan adalah kriteria mengenai lingkup, tujuan, manfaat, prinsip, mekanisme, prosedur, dan instrumen penilaian hasil belajar peserta didik yang digunakan sebagai dasar dalam penilaian hasil belajar peserta didik pada pendidikan dasar dan pendidikan menengah. Maka dengan mengacu pada Standar Penilaian Pendidikan, serta berdasarkan data-data yang diperoleh dari rapor mutu tahun 2017, kajian analisis kebutuhan pelatihan standar penilaian pada jenjang sekolah dasar di Kota Makassar dapat dianalisis dan 
dideskripsikan ke dalam beberapa aspek sub bahasan.

\section{Aspek Penilaian Sesuai dengan Ranah Kompetensi}

\section{Penilaian Mencakup Ranah Sikap, Pengetahuan dan Keterampilan}

Pada sub indikator ini sebanyak 413 sekolah atau 88,2\% telah mencapai Standar Nasional Pendidikan sisanya sebanyak 55 Sekolah atau 11,8 \% masih belum mencapai Standar Nasional Pendidikan. Standar Penilaian Pendidikan pada sub indikator ini meliputi hal-hal berikut yaitu penilaian sikap dilakukan oleh pendidik untuk memperoleh informasi deskriptif mengenai perilaku siswa. Penilaian pengetahuan dilakukan untuk mengukur penguasaan pengetahuan siswa. Penilaian keterampilan dilakukan untuk mengukur kemampuan siswa menerapkan pengetahuan dalam melakukan tugas tertentu. Penilaian pengetahuan dan keterampilan dilakukan oleh pendidik, satuan pendidikan, dan/atau Pemerintah. Jika standar mutu tidak tercapai maka Penilaian hasil belajar tidak dapat digunakan untuk mengukur dan mengetahui pencapaian kompetensi siswa. Penyebab tidak tercapainya standar mutu Perangkat penilaian terutama untuk penilaian sikap memiliki indikator penilaian yang tidak lengkap.

\section{Bentuk Pelaporan Penilaian sesuai dengan Ranah yang Dinilai}

Pada sub indikator ini sebanyak 303 sekolah atau $64,7 \%$ telah mencapai Standar Nasional Pendidikan sisanya sebanyak 165 Sekolah atau 35,3\% masih belum mencapai Standar Nasional Pendidikan. Standar Penilaian Pendidikan pada sub indikator ini meliputi hal-hal berikut yaitu hasil penilaian pencapaian pengetahuan dan keterampilan siswa disampaikan dalam bentuk angka dan/atau deskripsi. Penilaian aspek sikap dilakukan dengan mendeskripsikan perilaku siswa. Penilaian aspek pengetahuan dilakukan dengan melaporkan hasil penilaian dalam bentuk angka dengan skala 0-100 dan deskripsi. Penilaian aspek keterampilan dilakukan dengan melaporkan hasil penilaian dalam bentuk angka dengan skala 0-100 dan deskripsi. Jika Standar Mutu tidak tercapai maka pengukuran pencapaian kompetensi siswa tidak dapat diketahui dengan tepat. Pendidik tidak dapat memperbaiki proses pembelajaran. Prosedur penilaian yang dilakukan belum sesuai dengan peraturan yang ditentukan. Penyebab tidak tercapainya standar mutu Kemampuan pendidik untuk mendeskripsikan capaian siswa dalam bentuk kalimat yang mendidik masih terbatas. Pemahaman pendidik terhadap proses penilaian masih belum maksimal. Sering terjadinya perubahan peraturan yang berkaitan dengan penilaian

\section{Teknik Penilaian Obyektif dan Akuntabel}

\section{Jenis Teknik Penilaian yang Digunakan Obyektif dan Akuntabel}

Pada sub indikator ini sebanyak 145 sekolah atau $31 \%$ telah mencapai Standar Nasional Pendidikan sisanya sebanyak 323 Sekolah atau $69 \%$ masih belum mencapai Standar Nasional Pendidikan. Standar Penilaian Pendidikan pada sub indikator ini meliputi hal-hal berikut yaitu penilaian didasarkan pada prosedur dan kriteria yang jelas dan tidak dipengaruhi subjektivitas penilai. Prosedur penilaian, kriteria penilaian, dan dasar pengambilan keputusan dapat diketahui oleh pihak yang berkepentingan. Penilaian dapat dipertanggungjawabkan baik dari segi mekanisme, prosedur, teknik, maupun hasilnya. Perangkat penilaian dipertanggungjawabkan dalam bentuk laporan. Jika standar mutu tidak tercapai maka pengukuran pencapaian kompetensi siswa tidak dapat diketahui dengan tepat. Ketidakadilan bagi siswa yang berkebutuhan khusus dan memiliki perbedaan latar belakang. Pendidik tidak dapat memperbaiki proses pembelajaran. Prosedur penilaian yang dilakukan belum sesuai dengan peraturan yang ditentukan. penyebab tidak tercapai- 
nya standar mutu Pemahaman pendidik terhadap proses penilaian masih belum maksimal. Sering terjadinya perubahan peraturan yang berkaitan dengan penilaian. Sekolah belum mampu mengembangkan perangkat penilaian.

\section{Kelengkapan perangkat teknik penilaian}

Pada sub indikator ini sebanyak 130 sekolah atau $27,8 \%$ telah mencapai Standar Nasional Pendidikan sisanya sebanyak 338 Sekolah atau 72,2 \% masih belum mencapai Standar Nasional Pendidikan. Standar Penilaian Pendidikan pada sub indikator ini meliputi hal-hal berikut yaitu instrumen penilaian yang digunakan oleh pendidik dalam bentuk penilaian berupa tes, pengamatan, penugasan perseorangan atau kelompok, dan bentuk lain yang sesuai dengan karakteristik kompetensi dan tingkat perkembangan siswa. Instrumen penilaian yang digunakan oleh satuan pendidikan dalam bentuk penilaian akhir dan/atau ujian sekolah memenuhi persyaratan substansi, konstruksi, dan bahasa, serta memiliki bukti validitas empirik. Memiliki prosedur penilaian, kriteria penilaian, dan dasar pengambilan keputusan yang dapat diketahui oleh pihak yang berkepentingan. Jika standar mutu tidak tercapai maka Pengukuran pencapaian kompetensi siswa tidak dapat diketahui dengan tepat. Ketidakadilan bagi siswa yang berkebutuhan khusus dan memiliki perbedaan latar belakang. Pendidik tidak dapat memperbaiki proses pembelajaran. Prosedur penilaian yang dilakukan belum sesuai dengan peraturan yang ditentukan. Penyebab tidak tercapainya standar mutu adalah Pemahaman pendidik terhadap proses penilaian masih belum maksimal. Sering terjadinya perubahan peraturan yang berkaitan dengan penilaian. Sekolah belum mampu mengembangkan perangkat penilaian secara mandiri.

\section{Penilaian pendidikan ditindaklanjuti}

\section{Menindaklanjuti hasil pelaporan penilaian}

Pada sub indikator ini sebanyak 383 sekolah atau $81,8 \%$ telah mencapai Standar Nasional Pendidikan sisanya sebanyak 85 Sekolah atau 18,2 \% masih belum mencapai Standar Nasional Pendidikan. Standar Penilaian Pendidikan pada sub indikator ini meliputi hal-hal berikut yaitu ditindaklanjuti untuk memperbaiki proses pembelajaran. Ditindaklanjuti untuk melakukan perbaik-an dan/atau penjaminan mutu pendidikan pada tingkat satuan pendidikan. Ditindaklanjuti untuk menetapkan kriteria ketuntasan minimal serta kriteria dan/atau kenaikan kelas siswa. Program penilaian hasil belajar ditinjau secara periodik berdasarkan data kegagalan/kendala pelaksanaan program termasuk temuan penguji eksternal. Semua guru mengembalikan hasil kerja siswa yang telah dinilai. Jika standar mutu tidak tercapai maka upaya peningkatan mutu pendidikan kurang optimal. Pencapaian kompetensi lulusan lambat. Kurang mendapatkan informasi perbaikan rencana penilaian yang lebih adil dan bertanggung jawab. Penyebab tidak tercapainya standar mutu adalah Pemahaman pendidik terhadap proses penilaian masih belum maksimal. Sering terjadinya perubahan peraturan yang berkaitan dengan penilaian. Kurangnya pembinaan dari pengawas dan penyelenggara pendidikan.

\section{Melakukan pelaporan penilaian secara periodik}

Pada sub indikator ini sebanyak 59 sekolah atau $12,6 \%$ telah mencapai Standar Nasional Pendidikan sisanya sebanyak 409 Sekolah atau 87,4 \% masih belum mencapai Standar Nasional Pendidikan. Standar Penilaian Pendidikan pada sub indikator ini meliputi hal-hal berikut yaitu kemajuan yang dicapai oleh peserta didik dipantau, didokumentasikan secara sistematis. Sekolah melaporkan 
hasil belajar sekolah, dan institusi di atasnya. Pelaporan proses belajar dan hasil belajar oleh pendidik dilakukan oleh wali kelas atau guru kelas. Pelaporan penilaian dilakukan oleh pendidik disampaikan kepada peserta didik dan orang tua dalam bentuk rapor dan/atau paspor keterampilan yang berisi tentang skor disertai dengan deskripsi capaian kompetensi. Pendidik memiliki dokumen laporan hasil penilaian pada setiap akhir semester atau tahun dalam bentuk laporan prestasi belajar siswa. Laporan hasil penilaian pendidikan pada akhir semester dan akhir tahun ditetapkan dalam rapat dewan pendidik berdasar hasil penilaian oleh Satuan Pendidikan dan hasil penilaian oleh Pendidik. Jika standar mutu tidak tercapai maka Upaya peningkatan mutu pendidikan kurang optimal. Pencapaian kompetensi lulusan lambat. Siswa dan orangtua tidak mendapatkan masukan untuk perbaikan kemampuan belajar siswa. Penyebab tidak tercapai standar mutu adalah pemahaman pendidik terhadap proses penilaian masih belum maksimal. Sering terjadinya perubahan peraturan yang berkaitan dengan penilaian. Kurangnya pembinaan dari pengawas dan penyelenggara pendidikan.

\section{Instrumen Penilaian Menyesuaikan Aspek}

\section{Instrumen Penilaian Aspek Sikap}

Pada sub indikator ini sebanyak 124 sekolah atau 26,5\% telah mencapai Standar Nasional Pendidikan sisanya sebanyak 344 Sekolah atau 73,5 \% masih belum mencapai Standar Nasional Pendidikan. Standar Penilaian Pendidikan pada sub indikator ini meliputi hal-hal berikut yaitu penilaian aspek sikap dilakukan melalui observasi/pengamatan dan teknik penilaian lain yang relevan. Jika standar mutu tidak tercapai maka instrumen tidak dapat digunakan sebagai pengendalian standar mutu penilaian. Tingkat pencapaian kompetensi siswa tidak dapat terukur. Penyebab tidak tercapainya standar mutu adalah pendidik pada umumnya belum mampu menyusun instrumen penilaian dengan benar. Jumlah siswa melebihi kemampuan pendidik dalam melakukan penilaian.

\section{Instrumen Penilaian Aspek Pengetahuan}

Pada sub indikator ini sebanyak 140 sekolah atau 29,9\% telah mencapai Standar Nasional Pendidikan sisanya sebanyak 328 Sekolah atau 70,1\% masih belum mencapai Standar Nasional Pendidikan. Standar Penilaian Pendidikan pada sub indikator ini meliputi hal-hal berikut yaitu penilaian aspek pengetahuan dilakukan melalui tes tertulis, tes lisan, dan penugasan sesuai dengan kompetensi yang dinilai. Jika standar mutu tidak tercapai maka instrumen tidak dapat digunakan sebagai pengendalian standar mutu penilaian. Tingkat pencapaian kompetensi siswa tidak dapat diketahui. Penyebab tidak tercapainya standar mutu adalah Pendidik pada umumnya belum mampu menyusun instrumen penilaian dengan benar. Jumlah siswa melebihi kemampuan pendidik dalam melakukan penilaian.

\section{Instrumen Penilaian Aspek Keterampilan}

Pada sub indikator ini sebanyak 108 sekolah atau $23,1 \%$ telah mencapai Standar Nasional Pendidikan sisanya sebanyak 360 Sekolah atau 76,9 \% masih belum mencapai Standar Nasional Pendidikan. Standar Penilaian Pendidikan pada sub indikator ini meliputi hal-hal berikut yaitu penilaian keterampilan dilakukan melalui praktik, produk, proyek, portofolio, dan/atau teknik lain sesuai dengan kompetensi yang dinilai. Jika standar mutu tidak tercapai maka instrumen tidak dapat digunakan sebagai pengendalian standar mutu penilaian. Tingkat pencapaian kompetensi siswa tidak dapat diukur. Penyebab tidak tercapainya standar mutu adalah pendidik pada umumnya tidak menyusun Instrumen penilaian dengan benar. Jumlah siswa melebihi kemampuan pendidik melakukan penilaian. 


\section{Penilaian Dilakukan Mengikuti Prosedur}

\section{Prosedur Penilaian Berdasarkan Penyelenggara Penilaian}

Pada sub indikator ini sebanyak 71 sekolah atau $15,2 \%$ telah mencapai Standar Nasional Pendidikan sisanya sebanyak 397 Sekolah atau 84,8 \% masih belum mencapai Standar Nasional Pendidikan. Standar Penilaian Pendidikan pada sub indikator ini meliputi hal-hal berikut yaitu: 1) Prosedur penilaian pendidikan dilakukan melalui: a. Penilaian hasil belajar oleh pendidik; b. Penilaian hasil belajar oleh sekolah; c. Penilaian hasil belajar oleh pemerintah. 2) Prosedur penilaian oleh Pendidik: a. Pendidik menetapkan tujuan penilaian melalui telaah/ analisis $\mathrm{KI} / \mathrm{KD}$; b. Pendidik menyusun kisi-kisi penilaian; c. Pendidik merancang instrumen dan pedoman penilaian; $d$. Pendidik melakukan analisis kualitas instrumen berkaitan dengan persebaran, tingkat kesulitan, materi, bahasa; e. Pendidik melakukan penilaian pada aspek sikap, pengetahuan dan keterampilan; f. Pendidik melakukan pengolahan dan analisis dan menginterpretasikan hasil; g. Pendidik melaporkan hasil penilaian; $h$. Pendidik memanfaatkan hasil penilaian. 3) Prosedur penilaian oleh sekolah: a. Sekolah menetapkan KKM; b. Sekolah menyusun kisi-kisi penilaian; c. Sekolah meran-cang instrumen dan pedoman penskoran; d. Sekolah melakukan analisis kualitas instrumen berkaitan dengan persebaran, tingkat kesulitan, materi, bahasa; e. Sekolah melakukan penilaian pada aspek sikap, pengetahuan dan keterampilan; f. Sekolah melakukan pengolahan dan analisis dan menginterpretasikan hasil; g. Satuan pendidik melaporkan hasil penilaian; dan h. Sekolah memanfaatkan laporan penilaian sebagai evaluasi pendidikan

Jika standar mutu tidak tercapai maka pengukuran pencapaian kompetensi siswa tidak dapat diketahui. Pendidik tidak dapat memperbaiki proses pembelajaran. Prosedur penilaian dilakukan belum sesuai dengan peraturan yang ditetapkan. Penyebab tidak tercapainya standar mutu adalah Penyebab Tidak Tercapainya Standar Mutu Pemahaman pendidik terhadap proses penilaian masih belum maksimal. Sering terjadinya perubahan peraturan yang berkaitan dengan penilaian.

\section{Prosedur Penilaian Dilakukan \\ Berdasarkan Ranah yang Akan Dinilai}

Pada sub indikator ini tidak ada sekolah mencapai Standar Nasional Pendidikan artinya sebanyak 468 Sekolah atau $100 \%$ masih belum mencapai Standar Nasional Pendidikan. Standar Penilaian Pendidikan pada sub indikator ini meliputi hal-hal berikut yaitu: 1) Penilaian aspek sikap dilakukan melalui tahapan: a. mengamati perilaku siswa selama pembelajaran; b. mencatat perilaku siswa dengan menggunakan lembar observasi/pengamatan; c. menindaklanjuti hasil pengama$\tan$; dan d. mendeskripsikan perilaku siswa. 2) Penilaian aspek pengetahuan dilakukan melalui tahapan: a. menyusun perencanaan penilaian; $b$. Mengembangkan instrumen penilaian; c. melaksanakan penilaian; d. memanfaatkan hasil penilaian; dan e. melaporkan hasil penilaian dalam bentuk angka dengan skala 0-100 dan deskripsi. 3) Penilaian aspek keterampilan dilakukan melalui tahapan: a. menyusun perencanaan penilaian; $b$. mengembangkan instrumen penilaian; c. melaksanakan penilaian; d. memanfaatkan hasil penilaian; dan e. melaporkan hasil penilaian dalam bentuk angka dengan skala 0-100 dan deskripsi.

Jika standar mutu tidak dicapai maka Pengukuran pencapaian kompetensi siswa tidak dapat diketahui. Pendidik tidak dapat memperbaiki proses pembelajaran. Prosedur penilaian dilakukan belum sesuai dengan peraturan yang ditetapkan. Penyebab tidak tercapainya standar mutu adalah Pemahaman pendidik terhadap proses penilaian masih belum maksimal. Sering terjadinya perubahan peraturan yang berkaitan dengan penilaian 


\section{Kelulusan Siswa Berdasarkan Pertimbangan yang Sesuai}

Pada sub indikator ini sebanyak 413 sekolah atau $88,2 \%$ telah mencapai Standar Nasional Pendidikan sisanya sebanyak 55 Sekolah atau 11,8 \% masih belum mencapai Standar Nasional Pendidikan. Standar Penilaian Pendidikan pada sub indikator ini meliputi hal-hal berikut yaitu: 1) Kenaikan kelas dan kelulusan siswa dari satuan pendidikan ditetapkan melalui rapat dewan pendidik. 2) Pertimbangan penentuan kelulusan siswa: a. Menyelesaikan seluruh program pembelajaran; b. Ujian sekolah; c. Ujian sekolah berstandar nasional; d. Penilaian sikap; e. Penilaian pengetahuan; dan $\mathrm{f}$. Penilaian keterampilan.

Jika standar mutu tidak tercapai maka Pengukuran pencapaian kompetensi siswa tidak dapat diketahui dengan tepat. Ketidakadilan bagi siswa yang berkebutuhan khusus dan memiliki perbedaan latar belakang. Penyebab tidak tercapainya standar mutu adalah sering terjadinya perubahan peraturan yang berkaitan dengan penilaian.

\section{PENUTUP}

Berdasarkan hasil penelitian terhadap responden di sekolah dasar di Kota Makassar, pemenuhan standar peniliaian pendidikan masuk dalam kategori menuju Standar Nasional Pendidi-kan 4. Upaya peningkatan kemampuan guru dalam melakukan penilaian dalam pembelajaran masih perlu ditingkatkan untuk mencapai kategori Standar Nasional Pendidikan sesuai dengan Peraturan Menteri Pendidikan dan Kebudayaan Nomor 23 Tahun 2016 Tentang Standar Penilaian Pendidikan.

Penelitian ini masih memiliki banyak keterbatasan, misalnya terlalu kecilnya jumlah sampel dan kurang mendalamnya kajian tentang analisis kebutuhan. Oleh karena itu, tidak menutup kemungkinan penelitian lebih lanjut, dengan data yang lebih besar atau aspek kajian yang lebih tajam, mendalam dan luas meliputi delapan Standar Nasional Pendidikan.

\section{UCAPAN TERIMAKASIH}

Peneliti menghaturkan terimakasih kepada pimpinan dan staf LPMP Sulawesi Selatan, khususnya di bidang Pemetaan dan Supervisi Mutu Pendidikan, atas akses data yang diberikan.

\section{DAFTAR PUSTAKA}

Ali, M. (2014). Memahami riset perilaku dan sosial. Jakarta: Bumi Aksara.

Creswell, J.W. (2014). Research design pendekatan metode kualitatif, kuantitatif, dan campuran, edisi 4. Yogyakarta: Pustaka Pelajar.

Kemendikbud (2017). Pemetaan Mutu Pendidikan.

Kemendikbud (2017). Instrumen Pemetaan Mutu Pendidikan.

Kemendikbud (2017). Petunjuk Teknis Pengumpulan Data Peta Mutu Satuan Pendidikan.

Permendikbud No. 81A Tahun 2013 tentang Implementasi Kurikulum.

Permendikbud No.66 Tahun 2013 tentang Standar Penilaian Pendidikan .

Permendikbud No.23 Tahun 2016 tentang Standar Penilaian Pendidikan .

Sudjana. (2013). Metode statistika. Bandung: PT Tarsito Bandung. 